\title{
The Effect of Sleep Duration on Youth School Adjustment Mediated by Parenting Behavior
}

\author{
Soo Jung Kim, Ick-Joong Chung \\ Department of Social Welfare, Ewha Womans University, Seoul, Korea \\ 초중고생의 수면 시간이 부모양육태도의 매개를 통해 \\ 학교적응에 미치는 영향 \\ 김수정, 정익중 \\ 이화여자대학교 사회복지학과
}

Objective: The purpose of this study was to investigate the relationship between sleep duration and school adjustment of elementary-, middle-, high-school youth and to verify the mediating effects of parenting behavior.

Methods: We analyzed the data from Wave 4 of the first-grade panel of elementary school and Waves 1 and 4 of the first-grade panel of middle school in Korean Children and Youth Panel Survey (KCYPS), including 1,703 fourth graders, 2,119 seventh graders, and 2,108 tenth graders. Multiple regression was used for the data analyses.

Results: The results of this study were as follows. First, longer sleep duration was associated with a higher level of school adjustment in fourth grade. In contrast, longer sleep duration was associated with a lower level of school adjustment in seventh and tenth grades. Second, longer sleep duration was related to a higher level of discipline through reasoning in fourth grade. However, longer sleep duration was related to a lower level of parental monitoring in seventh and tenth grades. Third, the relationship between sleep duration and school adjustment was mediated by parenting behavior. Discipline through reasoning had a mediating effect in fourth grade, but the mediating effect of parental monitoring was found in seventh and tenth grades.

Conclusion: These results suggest a differentiated approach on sleep duration in accordance with developmental stage and the need for parent education.

Keywords: sleep duration, school adjustment, parenting behavior, parental monitoring, overprotection, discipline through reasoning$$
\text { 서론 }
$$

수면은 신체적인 피로뿐만 아니라 지친 뇌가 휴식을 취하고 그 기능을 회복하기 위해 매우 중요하다. 특히 수면은 아동과 청소년의 신체적, 정신적 건강에 필수적인 요소로서 불충분한

Corresponding Author: Ick-Joong Chung, Department of Social Welfare, Ewha Womans University, 52 Ewhayeodae-gil, Seodaemun-gu, Seoul 03760, Korea

E-mail: ichung@ewha.ac.kr
\end{abstract}

수면은 신체적 문제, 정서적 문제, 학교적응 등 여러 영역에 부 정적인 영향을 미친다(Beebe, 2011; H. J. Park, 2015; Rhie, Lee, \& Chae, 2011; Shochat, Cohen-Zion, \& Tzischinsky, 2014).

수면과 관련하여 우리나라뿐만 아니라 전 세계 여러 나라 의 아동과 청소년들은 초등학교에 입학하면서 학교생활에 적

(C)The Korean Association of Child Studies

This is an Open Access article distributed under the terms of the Creative Commons Attribution Non-Commercial License (http:// creativecommons.org/licenses/by-nc/4.0) which permits unrestricted noncommercial use, distribution, and reproduction in any medium, provided the original work is properly cited. 
응해야 하고 중·고등학교시기를 지나 가중되는 학업량과 인 터넷 사용의 증가 및 아르바이트 등으로 인해 수면 시간이 점 차 줄어들고 있다. 특히 입시 과열 경쟁 속에 있는 우리나라의 경우, 학습을 위해 부모들이 자녀의 수면 시간을 강제로 제한 하는 경우도 찾아볼 수 있다. 이러한 현실을 반영하듯이 우리 나라의 초중고생의 수면 실태를 살펴보면, 전국의 12,000 가구 만 10 세 이상 가구원 약 28,000 명을 조사한 결과에서 평균적으 로 초등학생은 9 시간 03 분, 중학생은 8 시간 18 분, 고등학생은 7시간 29 분으로 학년이 올라 갈수록 수면 시간이 감소하는 것 으로 나타났다(Statistics Korea, 2014). 한국질병관리본부의 제 7차 청소년 건강행태 온라인 조사에서도 중학생의 수면 시간 은 평균적으로 7.06 시간, 고등학생은 5.69시간으로 나타나 통 계청에서 제시한 결과보다 더 짧은 것으로 나타났다(J. G. Lee, Kang, Rhie, \& Chae, 2013). 초중고생의 수면 시간을 2015년에 미국의 수면재단(National Sleep Foundation [NSF])에서 권고하 고 하고 있는 기준 즉, 6-13세의 경우 9-11시간 수면, 14-17세 의 경우 8-10시간 수면에 비추어 볼 때 전반적으로 초중고생 모두 그 기준에 못 미치지만 특히 고등학생의 경우는 현격한 차이가 있음을 확인할 수 있다(Hirshkowitz et al., 2015).

수면 시간은 사회생활을 하는데 필요한 경험을 습득하 는 시기에 있는 초중고생의 학교적응에 영향을 미친다(Choi, 2012). 이와 관련하여 선행 연구에서는 대부분 짧은 수면 시간 이 아동과 청소년의 학교적응에 부정적인 영향을 미친다는 것 을 강조하였다(Dewald, Meijer, Oort, Kerkhof, \& Bogels, 2010; Lazaratou, Dikeos, Anagnostopoulos, Sbokou, \& Soldatos, 2005; Wolfson \& Carskadon, 1998). 예를 들어, Gruber 등(2010)은 미 국의 건강한 7-11세의 아동 39명을 대상으로 수면과 각성 상 태를 판별하기 위해 손목에 착용하는 액티그래프(actigraphy) 방법을 통해 수면 시간이 정서 및 행동 문제, 지능, 학업성취, 유급(grade repetition), 다른 학교 문제, 스포츠 참여와 기량에 있어서의 유능함 등 학교적응에 미치는 영향을 살펴보았다. 연구결과에서는 수면 시간이 길수록 IQ, 학업성취, 유능함 등 에 긍정적인 영향을 미쳤지만 정서 및 행동 문제에 유의한 영 향을 미치지 않았다. Drake 등(2003)의 연구에서는 11-15세 의 청소년을 대상으로 수면 습관과 학교적응의 관계를 살펴 본 결과, 수면 시간이 짧아질수록 주간 졸림 증상이 증가하였 고, 주간 졸림 증상이 증가할수록 수업 만족, 학업성취 등이 감 소하는 것으로 나타났다. Chung와 Cheung (2008)의 연구에서 는 홍콩의 12-19세 청소년 1,629명을 조사한 결과, 우수한 학 업성취를 보이는 중고등학생은 주중에 일찍 취침하고, 긴 수 면 시간을 가지는 것으로 나타났다. 스위스의 13-18세 청소년
132,716 명을 조사한 결과에서도 8 시간 이하의 짧은 수면 시 간을 취하는 청소년이 수면 시간이 긴 청소년에 비해 더 피곤 하거나 삶에 대해 덜 긍정적이며 낮은 학업성취를 나타냈다 (Perkinson-Gloor, Lemola, \& Grob, 2013).

짧은 수면이 문제일 수도 있지만 발달 단계에 따라서 긴 수 면도 문제가 될 수 있다. 이러한 긴 수면이 자포자기나 정신 건강 문제와 관련이 있을 수 있기 때문이다. Coulombe, Reid, Boyle와 Racine (2011)는 캐나다의 12-16세 청소년 980명을 대 상으로 인구학적 특성, 부모 특성, 가구 특성을 통제하여 분석 한 결과, 다른 사람에 비해 긴 수면이나 짧은 수면 시간은 주의 집중, 공격성, 우울·불안, 사회적 위축 문제의 증가에 유의한 영향을 미치는 것으로 보고하였다. 주의집중, 공격성 등 여러 정서 및 행동 문제의 공존 증상(co-morbidity) 가능성을 제시하 며 이 변수들을 동시에 통제한 결과에서는 긴 수면 시간은 공 격성의 증가에 유의한 영향을 미치는 것으로 나타났다. 국내 의 J. G. Lee 등(2013)의 연구에서도 13-16세 청소년 75,205명 을 조사한 결과, 6 시간 미만의 수면 시간을 갖는 집단의 우울 과 절망감 수준이 가장 높았고, 6 시간-8시간 미만이 가장 낮 았으며, 수면 시간이 9.5시간 이상으로 가장 길었던 집단에서 우울과 절망감 수준이 다시 증가하는 것으로 나타났다. 하지 만 긴 수면 시간에 대한 연구결과를 제시하거나 논의한 연구 들은 많지 않으며 특히 긴 수면이 학교적응 간의 관계에서 문 제가 될 수 있는지에 대해 살펴본 연구는 국내외적으로 미흡 하다.

한편, 부적절한 수면이 아동과 청소년의 다양한 발달 영 역에 미치는 부정적인 영향에 관한 연구는 많이 있지만 이들 간의 관계를 더욱 잘 이해하기 위해서는 수면이 어떠한 과정 을 통해서 학교적응에 영향을 미치는지 매개 과정을 살펴보 는 것이 필요하다(Shochat et al., 2014). 매개 과정 중에서 중요 하게 고려되는 요인 중의 하나는 부모의 양육태도이다(Bates, Viken, Alexander, Beyers, \& Stockton, 2002; Brand, Hatzinger, Beck, \& Holsboer-Trachsler, 2009a; Owens-Stively et al., 1997; Seifer, Sameroff, Dickstein, Hayden, \& Schiller, 1996). 즉, 아동 과 청소년이 건강한 수면 습관을 가지기 위해서는 부모의 감 독이나 통제가 필요한 것이다(Spilsbury et al., 2005). 이와 관련 하여 Owens-Stively 등(1997)은 평균적으로 5.7세의 수면문제 가 있는 80 여명의 유아와 수면문제가 없는 52 명의 유아를 살 펴본 결과, 부모의 감독이 부족한 느슨한 양육태도는 유아의 수면문제와 유의한 관계가 있는 것으로 나타났다. 9-13세 아 동 448명을 조사한 결과에서도 아동이 침대에 있는지를 확인 하기 위해 침대를 살펴보거나 평일 밤에 불을 끄는 등 자녀의 
수면을 관리해 주는 경우에 아동의 수면 시간이 증가하였다 (Meijer, Habekothe, \& van den Wittenboer, 2001). 부모의 양육 태도는 자녀가 적절한 수면 시간을 취하는데 중요한 역할을 한다고 주장한 de Jong 등(2012)의 연구에서도 4-13세 아동 4,072 명을 조사한 결과, 높은 수준의 애정과 높은 수준의 통 제를 보이는 권위적 양육태도가 아동의 긴 수면 시간과 유의 한 관계를 보이는 것으로 나타났다. 이는 청소년의 수면의 질 에도 유사한 경향을 보였는데 Brand 등(2009a)이 청소년 246 명을 조사한 결과, 칭찬이나 지지적인 긍정적 부모양육태도는 긍정적인 수면의 질에 영향을 미쳤지만 비난이나 비일관적인 부정적 양육태도는 부정적인 수면의 질과 유의한 관계가 있었 다.

그러나 이 연구들은 대부분 부모의 양육태도가 수면 시간 에 영향을 미쳐 여러 발달 영역에 영향을 미친다는 주장이지 만 반대의 가능성도 존재한다. 즉, 지금까지 부모 요인이 아동 에게 영향을 미친다는 부모효과에 대한 연구들이 대다수이지 만 대상아동의 연령이 높아질수록 점점 아동의 요인이 부모에 게 영향을 미친다는 아동효과에 대한 연구들이 증가하고 있다 (S. H. Jeong, 2009; Kerr \& Stattin, 2003; S. G. Lee, 2012; Reitz, Dekovic, Meijer, \& Engels, 2006). 예를 들어, Kim과 Chung (2015a)의 연구에서는 자녀가 부정적인 정서를 많이 표출하게 되면 부모의 온정성이나 반응성이 감소하였고, Kerr와 Stattin (2003)의 연구에서는 자녀의 비행으로 인해 부모의 통제가 축 소되어 굴복(yielding) 내지 방임효과가 나타나는 것으로 보고 하였다.

자녀의 부정적 정서성이나 비행 행동과 같은 일반적인 예 에서 자녀의 특성이 부모의 양육태도에 영향을 미친 것과 같 이 자녀의 수면문제가 부모의 양육태도 등 부모 요인에 영 향을 미칠 수 있다. 예를 들어, Sadeh, Tikotzky와 Scher (2010) 는 부모의 양육태도가 영아의 수면 문제에 중요한 영향을 미 칠 수도 있지만 반대로 영아의 수면 문제가 부모의 양육태도 에 영향을 미칠 수 있다고 하면서 양방향적 관계를 주장하였 다. Bae (2014)의 연구에서도 역시 영아의 수면문제는 어머니 의 애착을 감소시켜 문제행동을 일으키는 것으로 보고하였다. 스위스의 5-6세 유아 378명을 조사한 Smedje, Broman과 Hetta (1998)의 연구에서는 유아의 수면 문제는 부모의 수면 문제를 증가시키는 것으로 나타났는데 연구자들은 이것을 자녀의 수 면 문제가 부모의 수면 문제에 미치는 영향으로 해석하였다. 호주의 영유아 5,107명을 조사한 연구에서도 영아와 유아의 수면문제는 부모의 정신건강에 부정적인 영향을 미치는 것으 로 나타났다(Martin, Hiscock, Hardy, Davey, \& Wake, 2007).
이처럼 어린 영아나 유아의 수면 특성이 그들 부모의 특성 에 영향을 미친다는 연구결과는 점차 증가하고 있지만 상대 적으로 아동이나 청소년의 수면 특성이 부모의 특성에 영향 을 미친다는 아동효과 연구는 상대적으로 미흡하다(Brand, Gerber, Hatzinger, Beck, \& Holsboer-Trachsler, 2009b; Kalak et al., 2012). 예를 들어, 미국의 3-14세 아동의 부모를 조사한 Meltzer와 Mindell (2007)의 연구에서는 아동의 수면 박탈은 어 머니의 수면의 질, 우울, 양육 스트레스, 피로 등에 부정적인 영향을 미친다는 것을 입증하면서 아동의 수면과 부모의 특성 관계는 복잡하고 양방향적이라고 주장하였다. 스위스의 고등 학생 293명을 조사한 Brand 등(2009b)의 연구에서도 청소년의 수면 패턴이 부모의 수면 패턴이나 양육태도와 상관관계가 있 는 것으로 나타났다. 이상에서 어린 영유아뿐만 아니라 아동 과 청소년의 수면 문제는 부모의 양육태도 등의 부모 특성에 영향을 미칠 것으로 판단되지만 이러한 연구가 아직 부족하기 에 아동이나 청소년의 수면 문제가 부모의 양육태도에 영향을 미치는지 확인해 보는 것이 필요하다. 즉, 자녀가 항상 너무 늦 게 자거나 많이 자거나 혹은 적게 자면 결국 방임하는 식으로 부모의 양육태도에 영향을 미칠 수 있으므로 자녀의 수면 패 턴이 부모의 양육태도에 어떠한 영향을 미쳐서 학교적응에 이 르는지 확인해 보아야 한다.

한편 국내외적으로 이러한 연구는 아직까지 충분히 수행되 지 못했는데 특히 국내의 경우, 수면 연구는 최근까지 많은 관 심을 받지 못하였고, 수면에 관한 기초자료도 부족한 실정이 다. 지금까지 국내에서 초중고생을 대상으로 수행된 수면에 관한 연구는 수면 패턴이나 수면 문제의 실태(Seo et al., 2008; Song, Park, Nam, \& Kim, 2000; Yang, Kim, Patel, \& Lee, 2005; Yoo, 2004), 수면 시간과 자살생각/정서 문제/비만과의 관계 (Ha \& Park, 2014; J.-H. Jeong, Jang, Lee, Shim, \& Choi, 2013; J. G. Lee et al., 2013; H. J. Park, 2015) 등에 관한 연구가 있을 뿐 이다. 수면과 학교적응에 관한 연구는 Rhie 등(2011)과 Choi (2012)의 두 편의 연구가 있는데 Rhie 등(2011)의 연구의 경우, 초등학교 5학년-고등학교 3학년 3,370명을 대상으로 수면 시 간과 주간 졸림 증상의 관계와 주간 졸림 증상과 학교적응과 의 관계를 살펴보았지만 이 연구에서는 수면이 어떠한 과정 을 통해서 학교적응에 종국적으로 영향을 미치는지를 밝히지 못하였다. 또한 Choi (2012)의 연구에서는 초등학교 5-6학년 과 중학교 1-3학년 509명을 대상으로 수면 시간과 학교적응 간의 관계에서 우울과 자기보호능력의 매개효과를 살펴보았 다. 연구결과에서는 수면 시간이 학교적응에 직접적으로 영향 을 미치지 않지만 우울과 자기보호능력을 매개하여 학교적응 
에 간접적으로 부정적인 영향을 미치는 것으로 나타났다. 하 지만 이 연구에서도 초등학생과 중학생을 함께 분석하여 짧은 수면의 부정적인 영향만을 강조하였고, 수면과 학교적응 간 의 관계에서 중요하게 고려되어지는 부모양육태도나 다른 변 수들을 포함시키지 못하였다(Labree et al., 2015; Philips, Sioen, Michels, Sleddens, \& de Henauw, 2014). 그러므로 우리나라 초 중고생의 보다 나은 학교적응을 위해서는 수면 시간이 짧아 지거나 길어질 때 학교적응에 미치는 영향 관계와 부모의 양 육태도가 어떻게 이들 간의 관계를 매개하는지 살펴보는 것이 필요하다. 이때 학교적응에 영향을 미칠 수 있는 개인 요인, 부 모 요인, 가구 요인 등 다른 변수들을 통제한다면 명확한 영향 관계를 살펴볼 수 있을 것이다(BaHammam, Al-Faris, Shaikh, \& Saeed, 2006; Bruni et al., 2006; Fredriksen, Rhodes, Reddy, \& Way, 2004; B. H. Lee \& Kang, 2014; Y. H. Park, 2014).

따라서 본 연구에서는 한국아동청소년패널 자료를 사용하 여 초중고생의 수면 시간과 학교적응 간의 관계에서 부모의 양육태도가 매개요인의 역할을 하는지 살펴보고자 한다. 이를 위해 본 연구에서는 성별, 컴퓨터/게임오락시간, TV/Video 시 청시간, 부모학력, 취업유무, 가구 구조 등이 통제변수로 포함 될 것이다. 본 연구의 결과는 초중고생의 수면 시간이 학교적 응에 미치는 영향에 대해 보다 실증적이고 체계적인 이해를 돕고, 초중고생의 수면문제를 개선하는데 기초 자료를 제공할 것이다. 본 연구의 연구문제는 다음과 같다.

\section{연구문제 1}

초4, 중1, 고1의 수면 시간에 따라 학교적응 수준에 차이가 있 는가?

\section{연구문제 2}

초4, 중1, 고1의 수면 시간이 학교적응 수준에 미치는 영향에 서 부모의 양육 태도가 매개역할을 하는가?

\section{연구방법}

\section{연구대상}

본 연구에서는 한국청소년정책연구원의 한국아동청소년패 널(Korea Children and Youth Panel [KCYP]) 자료 중에서 초등 학교 1학년 대상으로 한 패널의 4학년 자료와 중학교 1학년을 대상으로 한 패널의 중학교 1학년, 고등학교 1 학년 자료를 사
용하였다. 한국아동청소년패널은 층화다단계집락추출 방법 을 사용하여 전국에 걸쳐 표본을 추출한 것으로서 2010년을 기준으로 하여 향후 7 년간 매년 1 회 개인의 성장 및 발달과 환 경 등에 대해 반복 추적 조사하는 전국적 대표성이 높은 패널 이다. 본 연구에서 초등학교 4학년, 중학교 1학년, 고등학교 1 학년을 선택한 이유는 학년이 올라갈수록 가중되는 학업량 과 게임 등의 인터넷 사용이나 스마트폰 사용으로 인해 충분 한 수면을 취하기가 어려워지므로 이 시기의 수면 시간이 학 교적응에 영향을 미칠 가능성이 높은 시기라고 판단되었기 때문이다. 특히 초등학교 4학년 경우, 학령기 전기에서 후기 로, 중학교 1학년은 초등학교에서 중학교로, 고등학교 1학년 은 중학교에서 고등학교로 전이하는 첫 시기로서 대표 학년 일 뿐만 아니라 다른 학년과 달리 본 연구에서 매개변수에 해 당하는 양육태도에 대한 조사 문항을 패널조사에 포함한 학 년에 해당하므로 초 4 , 중 1 , 고 1 을 선정하였다. 본 연구의 최 종 분석 대상으로 초등학교 4학년은 2,119명, 중학교 1학년은 2,251 명, 고등학교 1학년은 2,108 명이었다.

\section{연구도구}

\section{독립변수: 수면 시간}

수면 시간은 등교일과 비등교일을 구분하여 “보통 몇 시 몇 분에 자고 몇 시 몇 분에 일어나나요?”라는 문항을 이용하여 측정하였다. 문항의 응답 방식은 자기보고식으로 초중고생 이 직접 응답하도록 되어있다. 분석을 위해 수면 시간은 취침 시간과 기상시간을 통해 계산하였으며 일반적으로 비등교일 의 수면 시간이 불규칙하고 적정 권고 기준이 부재하기 때문 에 본 연구에서는 일상적인 패턴을 확인할 수 있는 등교일 수 면 시간만을 사용하였다. 그리고 초4, 중 1 , 고 1 의 수면 시간에 따른 학교적응 수준의 차이를 살펴보기 위해 2015년 미국 수 면재단의 권고 기준을 적용하여 초등학교 4학년의 수면 시간 은 9시간 미만, 9시간-11시간(적정 수면 시간), 11시간 초과 로, 중학교 1학년과 고등학교 1학년의 수면 시간은 8시간 미 만, 8 시간-10시간(적정 수면 시간), 10 시간 초과로 구분하였 다(Hirshkowitz et al., 2015).

\section{종속변수: 학교적응}

본 연구의 종속변수에 해당하는 학교적응은 Min (1991)이 초 등학생용으로 제작한 척도를 한국아동청소년패널 조사에서 
수정 - 보완한 도구로 측정하였다. 학교적응은 학습활동 5 문항 (예: “학교 수업 시간이 재미있나요?”), 학교규칙 5 문항(예: “당 번이나 1 인 1 역 등, 반에서 맡은 활동을 열심히 한다.”), 교우관 계 5 문항(예: “반 아이들과 잘 어울리나요?”), 교사관계 5 문항 (예: “선생님과 이야기하는 것이 편한가요?”)으로 구성되어 있 다. 각 문항의 응답방식은 4점 Likert 척도(매우 그렇다 = 1점, 전혀 그렇지 않다 $=4$ 점)로 이루어져 있으며, 모든 문항은 역코 딩하여 사용하였다. 점수가 높을수록 학교적응 수준이 높다는 것을 의미하며 본 연구에서 초4, 중 1 , 고 1 의 학교적응 수준에 대한 Cronbach's $\alpha=.79$ (초4), .79 (중1), .84 (고1)였다.

\section{매개변수: 부모양육태도}

본 연구의 매개변수에 해당하는 부모의 양육태도는 Huh (2000)의 척도를 사용하여 측정하였다. 부모의 양육태도는 감 독, 애정, 비일관성, 과잉기대, 과잉간섭, 합리적 설명의 6 개의 하위요인으로 이루어져 있다. 애정, 비일관성, 과잉기대는 상 대적으로 아동기와 관련성이 높으며 감독, 과잉간섭, 합리적 설명은 청소년기 특성과 밀접하게 관련되므로(Kim \& Chung, 2015b) 청소년기에 자녀의 수면 시간으로 인해 아동효과(child effect)가 발생하여 부모의 양육태도가 바뀔 수 있을 것으로 판 단되는 감독, 과잉간섭, 합리적 설명만을 매개변수로 선정하 였다. 본 연구에서는 감독 3 문항(예: "내가 시간을 어떻게 보내 는지 알고 계신다."), 과잉간섭 3문항(예: “작은 일에 대해서도 '이래라', ‘저래라' 간섭하신다.”), 합리적 설명 3문항(예: “부모 님[보호자]의 결정을 무조건 따르게 하기 보다는 왜 그래야 하 는지 설명해 주신다.”) 등 3 가지 하위요인을 사용하였다. 각 문 항의 응답방식은 4점 Likert 척도(매우 그렇다 $=1$ 점, 전혀 그렇 지 않다 $=4$ 점)로 이루어져 있고, 모든 문항은 역코딩하여 사용 하였다. 점수가 높을수록 부모감독, 과잉간섭, 합리적 설명 수 준이 높다는 것을 의미하며 부모감독, 과잉간섭, 합리적 설명 각각에 대한 Cronbach's $\alpha=.71, .69, .77$ (초4), .76, .64, .74 (중1), $.77, .72, .78$ (고1)이었다.

\section{통제변수: 개인요인, 부모요인, 가구요인}

본 연구에서 통제변수에 해당하는 개인요인은 성별, 컴퓨터/ 게임오락시간, TV/Video 시청시간으로 구성되었다. 먼저 성별 은 남(0), 여(1)로 구분하여 측정하였다. 그리고 컴퓨터/게임 오 락시간과 TV/Video 시청시간은 일주일간 이용시간을 등교일 과 비등교일로 구분하여 분 단위로 측정하였는데 본 연구에서
는 등교일(주중시간) 만을 사용하였다. 부모요인은 부모학력 과 취업유무를 사용하여 측정하였는데 부모 학력은 부모 모두 또는 부나 모 대졸 이상 (1)과 부모 모두 고졸 이하(0)로 구분하 였다. 그리고 취업 유무는 부모 모두 취업 유 또는 부나 모 취 업 유(1), 부모 모두 취업 무(0)로 구분하였다. 가구요인으로 가 구구조는 친아버지+친어머니(1), 기타(0)로 구분하여 사용하 였다. 추가적으로 고등학교의 경우에는 학교 유형을 포함하여 분석하였는데 일반계(1), 전문계(0)로 구분하였다.

\section{연구모형 및 분석 방법}

본 연구에서는 첫째, 연구대상의 주요 변수의 일반적 특성을 살펴보기 위해 빈도, 백분율, 평균, 표준편차 등을 산출하였 고, 신뢰도를 검증하기 위해 Cronbach's $\alpha$ 를 산출하였다. 둘 째, 초등학교 4학년, 중학교 1학년, 고등학교 1학년의 수면 시 간에 따라 학교적응 수준의 차이가 있는지를 살펴보기 위해 ANOVA 검정을 실시하였다. 셋째, 초등학교 4학년, 중학교 1 학년, 고등학교 1학년의 수면 시간과 학교적응간의 관계에서 부모양육태도의 매개효과를 살펴보기 위해 다중회귀분석과 Sobel test를 실시하였고, Baron과 Kenny (1986)가 제시한 3단계 매개효과 검증 절차를 적용하였다. 1 단계에서는 독립변수가 종속변수에 미치는 영향, 2 단계에서는 독립변수가 매개 변수 에 미치는 영향, 3 단계에서는 독립변수와 매개변수가 종속변 수에 미치는 영향을 살펴보았다.

\section{연구결과}

\section{주요 변수의 기술통계치}

본 연구의 주요변수에 대한 일반적인 특성을 살펴보기 위해 기술통계치를 살펴본 결과는 다음과 같다(Table 1).

먼저, 독립변수에 해당하는 수면 시간을 살펴보면, 초등학 교 4학년 평균 수면 시간은 8.90 시간 $(S D=.88)$ 으로 나타났다. 또한 중학교 1학년은 7.90 시간 $(S D=.98)$, 고등학교 1학년은 6.31 시간 $(S D=1.09)$ 으로 나타나 학년이 올라감에 따라 수면 시간이 점차 감소하는 경향을 나타냈다. 이는 Statistics Korea (2014)에서 발표한 수면 시간 즉, 초등학생 9시간 03분, 중학생 8시간 18분과 10-20여분 정도 차이가 있지만 고등학교 7시간 29 분과는 거의 1 시간 정도 차이가 있었다. 그 이유는 생활시간 이 조사시점이나 조사방법의 영향을 크게 받기 때문에 발생한 
Table 1

Descriptive Statistics of Major Variables

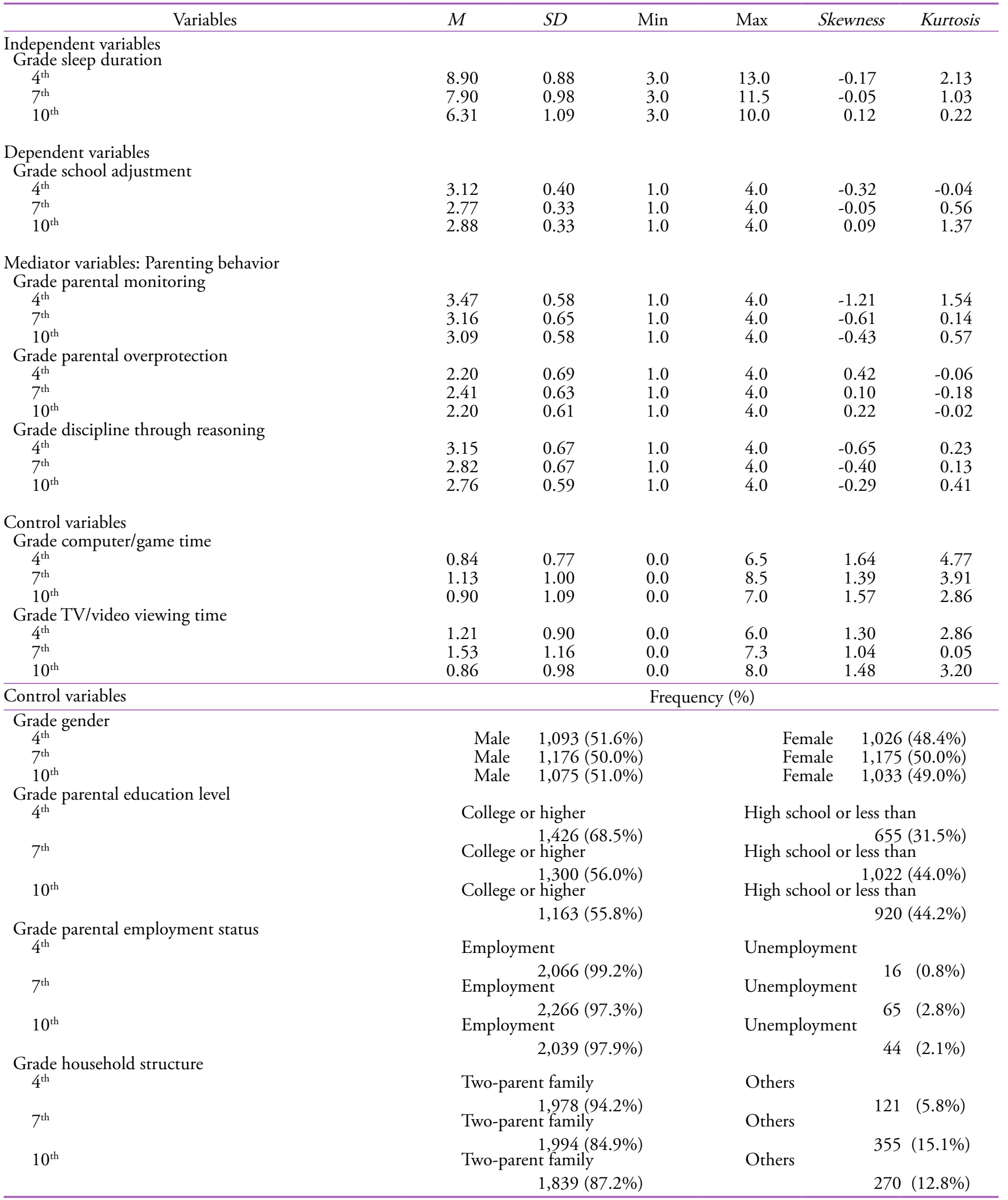


차이라고 생각된다. 종속변수에 해당하는 학교적응 수준을 살 펴보면, 초등학교 4학년의 학교적응의 평균 점수는 3.12점 $(S D$ $=.40)$ 으로 나타났다. 그러나 중학교 1학년은 2.77점 $(S D=.33)$, 고등학교 1학년은 2.89 점 $(S D=.33)$ 으로 초등학교에 비해 감소 하였으나 중고등학교에서는 비슷한 수준을 유지하였다.

한편, 매개변수에 해당하는 부모의 양육태도를 살펴보면, 부모 감독의 평균점수는 초등학교 4학년 3.47점 $(S D=.58)$, 중학교 1학년 3.16점 $(S D=.65)$, 고등학교 1학년 3.09점 $(S D=$ .58)으로 학년이 증가하면서 감소하는 추세를 보였고, 과잉간 섭의 평균점수는 초등학교 4학년 2.20 점 $(S D=.69)$, 중학교 1 학년 2.41점 $(S D=.63)$, 고등학교 1학년 2.20점 $(S D=.61)$ 으로 전반적으로 높지는 않았으나 중학교 1학년 시기가 가장 높은 것으로 나타났다. 부모의 합리적 설명의 평균점수는 초등학 교 4학년 3.15점 $(S D=.67)$, 중학교 1학년 2.82점 $(S D=.67)$, 고 등학교 1학년 2.76점 $(S D=.59)$ 으로 학년이 올라가면서 감소 하는 것으로 나타났다. 그리고 주요 변수 중에서 연속 변수의 왜도 (절대값 < 3)와 첨도(절대값 < 10)가 모두 정상분포의 조 건을 충족시키고 있었다.

\section{수면 시간에 따른 학교적응 수준의 차이}

초등학교 4학년, 중학교 1학년, 고등학교 1학년의 수면 시 간에 따라 학교적응 수준에 차이가 있는지 살펴보기 위해 ANOVA 검정을 실시한 결과는 Table 2와 같다.

연구결과에서는 초등학교 4학년 수면 시간, 중학교 1학년 수면 시간, 고등학교 1학년 수면 시간 집단이 모두 학교적응 수준 간에 통계적으로 유의한 차이가 있는 것으로 나타났다. 하위집단 간 차이를 알아보기 위해 Sheffé 검정을 실시한 결과,
초등학교 4학년은 9시간-11시간 집단이 9시간 미만인 집단 보다 학교적응 수준이 유의하게 높았다. 중학교 1학년은 8시 간 미만이 8-10시간 집단보다, 8 시간 미만이 10 시간 초과 집 단보다 학교적응 수준이 유의하게 높은 것으로 나타났다. 이 러한 결과에서 미국 수면재단의 권장 수면 시간이 6-13세의 경우에 9-11시간으로 우리나라 초등학생에게 적합하지만 반 면에 14-17세의 경우에 8-10시간이 우리나라 중고등학생에 게는 다소 맞지 않는다는 것을 확인할 수 있다. 미국 수면재단 의 기준에 따르면 적정 수면 시간을 초과한 학생이 초4는 21 명, 중1은 31 명, 고1은 한명도 없다는 결과에서 우리나라 상황 에 맞는 적절한 수면 시간 기준이 마련되어야 할 것으로 보인 다. 따라서 중고등학생의 경우에는 적정 수면 시간을 한 단계 낮추되 중학생과 고등학생에게 차별적으로 적용할 필요가 있 을 것으로 판단된다.

\section{수면 시간이 학교적응에 미치는 영향에서 부 모양육태도의 매개효과}

초등학교 4학년, 중학교 1학년, 고등학교 1학년의 수면 시간이 학교적응에 미치는 영향에서 부모의 양육태도의 매개효과를 살펴보기 위해 통제변수를 투입한 후 수면 시간이 학교적응에 미치는 영향(1단계), 수면 시간이 부모양육태도에 미치는 영향 (2단계), 수면 시간이 부모양육태도를 매개로 학교적응에 미치 는 영향(3단계)으로 구분하여 다중회귀분석을 실시하였다. 이 때 통제변수는 성별, 부모의 학력, 취업유무, 가구구조, 컴퓨터/ 게임시간, TV/Video 시청시간 등이 포함되었다. 투입된 변수 간 다중공선성을 확인하기 위해 살펴본 VIF 계수는 1.03-1.32 로 모두 1.5 이하로 다중공선성의 문제 가능성이 낮은 것으로

Table 2

Differences in School Adjustment According to Sleep Duration

\begin{tabular}{|c|c|c|c|c|c|}
\hline Variable & $N$ & $M$ & $S D$ & $F$ & Sheffé \\
\hline \multicolumn{6}{|l|}{$4^{\text {th }}$ grade } \\
\hline Less than 9 hours & 967 & 3.09 & 0.41 & $5.253^{* *}$ & $2>1^{*}$ \\
\hline $9-11$ hours & 1,127 & 3.15 & 0.39 & & \\
\hline More than 11 hours & 21 & 3.16 & 0.36 & & \\
\hline \multicolumn{6}{|l|}{$7^{\text {th }}$ grade } \\
\hline Less than 8 hours & 1,006 & 2.80 & 0.34 & $6.908^{* *}$ & $1>2^{*}$ \\
\hline $8-10$ hours & 1,214 & 2.75 & 0.33 & & $1>3^{*}$ \\
\hline More than 10 hours & 31 & 2.63 & 0.39 & & \\
\hline \multicolumn{6}{|l|}{$10^{\text {th }}$ grade } \\
\hline Less than 8 hours & 1,896 & 2.89 & 0.32 & $4.338^{*}$ & \\
\hline $8-10$ hours & 179 & 2.83 & 0.43 & & \\
\hline
\end{tabular}

${ }^{*} p<.05 .{ }^{* *} p<.01$. 
Table 3

Effect of Fourth-Grade Sleep Duration on School Adjustment Mediated by Parenting Behavior

\begin{tabular}{|c|c|c|c|c|c|}
\hline \multirow[b]{5}{*}{ Variable } & \multirow{4}{*}{$\begin{array}{c}\text { Step 1 } \\
\text { School } \\
\text { adjustment }\end{array}$} & \multicolumn{3}{|c|}{ Dependent variable } & \multirow{5}{*}{$\begin{array}{c}\text { Step } 3 \\
\text { School } \\
\text { adjustment } \\
\beta\end{array}$} \\
\hline & & & Step 2 & & \\
\hline & & \multicolumn{3}{|c|}{ Parenting behavior } & \\
\hline & & Monitoring & Overprotection & Reasoning & \\
\hline & $\beta$ & $\beta$ & $\beta$ & $\beta$ & \\
\hline \multicolumn{6}{|l|}{ Independent } \\
\hline Sleep duration & $.051^{*}$ & .005 & -.020 & $.045^{*}$ & $.033^{+}$ \\
\hline \multicolumn{6}{|l|}{ Mediator } \\
\hline Monitoring & & & & & $.267^{* * *}$ \\
\hline Overprotection & & & & & .006 \\
\hline Reasoning & & & & & $.360^{* * *}$ \\
\hline \multicolumn{6}{|l|}{ Control } \\
\hline Gender & $.117^{* * *}$ & $.105^{* * *}$ & $-.160^{* * *}$ & -.008 & $.092^{* * *}$ \\
\hline Computer/game & $-.101^{* * *}$ & $-.143^{* * *}$ & .013 & $-.071^{* *}$ & $-.038^{*}$ \\
\hline TV/video & $-.109^{* * *}$ & $-.083^{* * *}$ & $-.046^{*}$ & $-.101^{* * *}$ & $-.051^{* *}$ \\
\hline Education level & $.091^{* * *}$ & $.081^{* * *}$ & $-.050^{*}$ & $.058^{*}$ & $.049^{* *}$ \\
\hline Employment status & $-.056^{*}$ & $-.063^{* *}$ & .008 & -.011 & $-.036^{+}$ \\
\hline Family structure & $.076^{* *}$ & .031 & -.021 & $.063^{* *}$ & $.045^{*}$ \\
\hline Constant & $2.858^{* * *}$ & $3.507^{* * *}$ & $2.570^{* * *}$ & $2.775^{* * *}$ & $1.596^{* * *}$ \\
\hline Adjusted $R^{2}$ & .071 & .063 & .027 & .030 & .341 \\
\hline$F$ & $23.206^{* * *}$ & $20.463^{* * *}$ & $8.982^{* * *}$ & $9.884^{* * *}$ & $105.734^{* * *}$ \\
\hline
\end{tabular}

${ }^{+} p<.10 .{ }^{*} p<.05 .{ }^{* *} p<.01 .{ }^{* * *} p<.001$.

Table 4

Effect of Seventh-Grade Sleep Duration on School Adjustment Mediated by Parenting Behavior

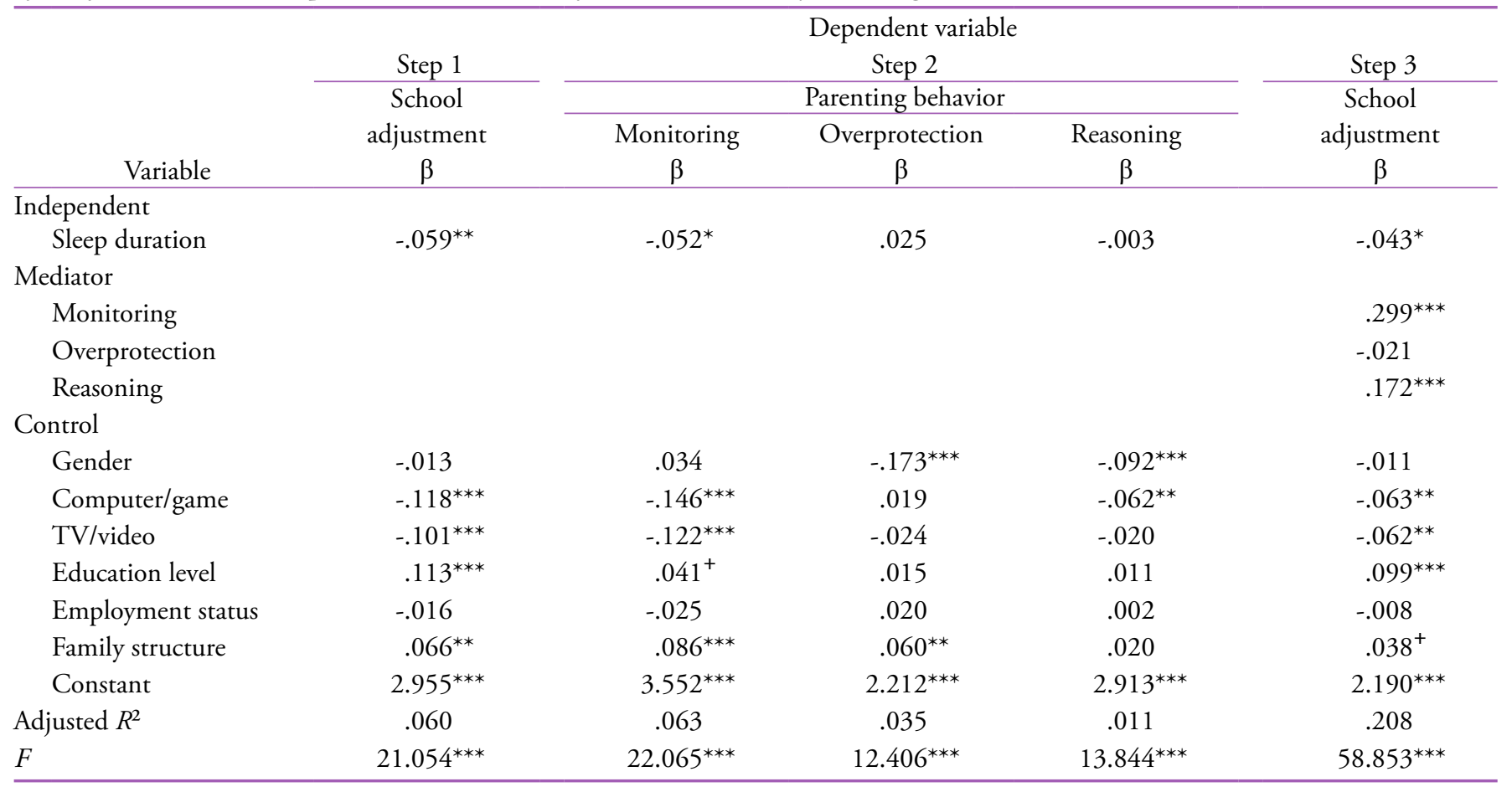

${ }^{+} p<.10 .{ }^{*} p<.05 .{ }^{* *} p<.01 .{ }^{* * *} p<.001$. 
Table 5

Effect of Tenth-Grade Sleep Duration on School Adjustment Mediated by Parenting Behavior

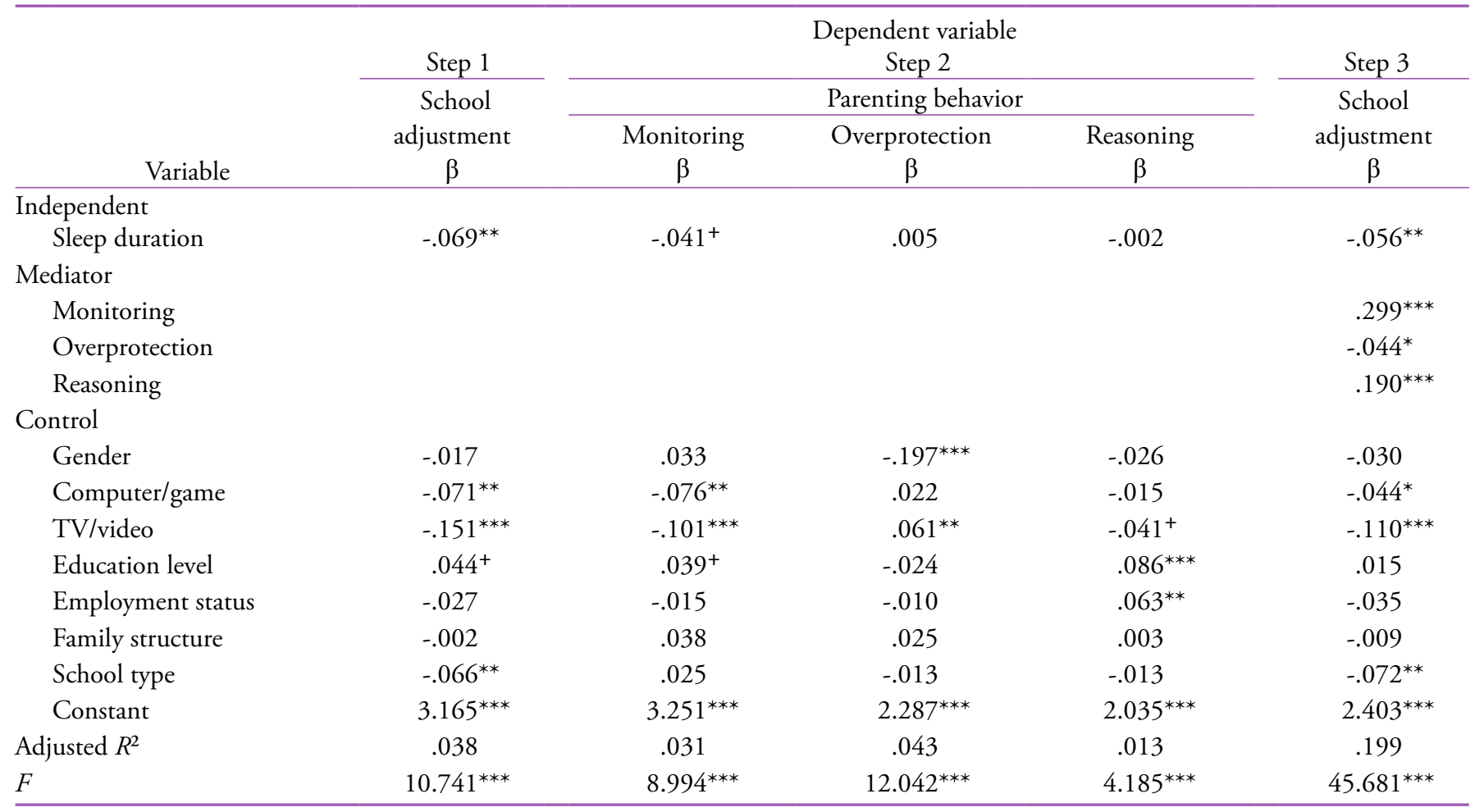

${ }^{+} p<.10 .{ }^{*} p<.05 .{ }^{* *} p<.01 .{ }^{* * *} p<.001$.

나타났다. 본 연구의 결과는 다음과 같다(Table 3-Table 5).

초등학교 4학년을 분석한 결과, 1 단계에서는 수면 시간이 학교적응에 유의한 정적(+) 영향을 미치는 것으로 나타났다 (Table 3). 이는 수면 시간이 증가할수록 학교적응 수준이 높아 진다는 것을 의미한다. 2 단계에서는 수면 시간이 합리적 설명 에 유의한 정적(+) 영향을 미쳤지만 부모감독과 과잉간섭에 유의한 영향을 미치지 않았다(2단계). 이는 수면 시간이 증가 할수록 부모의 합리적 설명 수준도 증가한다는 것을 의미한 다. 3 단계에서는 부모 감독, 합리적 설명이 학교적응에 유의한 정적(+) 영향을 미쳤지만 수면 시간, 과잉간섭이 학교적응에 유의한 영향을 미치지 않았다. 이는 부모의 감독 수준과 합리 적 설명이 높아질수록 학교적응 수준이 높아지는 것을 의미한 다. 3 단계의 수면 시간을 1 단계의 매개변수가 없을 때의 수면 시간과 비교했을 때 표준화회귀계수 $(\beta)$ 값이 작아지고 $p<.05$ 수준에서 학교적응에 유의하지 않은 결과에서 부모의 양육태 도는 수면 시간과 학교적응간의 관계에서 완전매개 역할을 하 는 것으로 볼 수 있다. 이러한 매개효과에 대해 살펴보기 위해 Sobel test를 실시한 결과, 부모양육태도 중에서 합리적 설명만 이 수면 시간과 학교적응 간의 관계에서 $z=2.637(p<.01)$ 로
유의하게 나타나 매개효과가 있는 것으로 나타났다.

중학교 1 학년을 분석한 결과, 1 단계에서는 수면 시간이 학 교적응에 유의한 부적(-)인 영향을 미치는 것으로 나타났다 (Table 4). 이는 수면 시간이 감소할수록 학교적응 수준이 높아 진다는 것을 의미한다. 2 단계에서는 수면 시간이 부모 감독에 유의한 부적(-) 영향을 미쳤지만 과잉간섭과 합리적 설명에 유 의한 영향을 미치지 않는 것으로 나타났다. 이는 수면 시간이 감소할수록 부모의 감독 수준이 증가한다는 것을 의미한다. 3 단계에서는 수면 시간이 학교적응에 유의한 부적(-)인 영향을 미치고, 부모감독과 합리적 설명은 학교적응에 유의한 정적 (+) 영향을 미치는 것으로 나타났다. 그러나 과잉간섭은 학교 적응에 유의한 영향을 미치지 않았다. 이는 수면 시간이 감소 할수록, 부모의 감독 수준과 합리적 설명이 높아질수록 학교 적응 수준이 높아진다는 것을 의미한다. 3 단계의 수면 시간을 1 단계의 매개변수가 없을 때의 수면 시간과 비교했을 때 표준 화회귀계수 $(\beta)$ 값이 작아지고 학교적응에 유의한 결과에서 부 모의 양육태도는 수면 시간과 학교적응간의 관계에서 부분매 개 역할을 하는 것으로 볼 수 있다. 이러한 매개효과에 대해 살 펴보기 위해 Sobel test를 실시한 결과, 부모양육태도 중에서 부 
모감독만이 수면 시간과 학교적응 간의 관계에서 $z=-3.680(p$ <.001) 유의하게 나타나 매개효과가 있는 것으로 나타났다.

고등학교 1 학년을 분석한 결과, 1 단계에서는 수면 시간이 학교적응에 유의한 부적(-)인 영향을 미치는 것으로 나타났다 (Table 5). 이는 수면 시간이 감소할수록 학교적응 수준이 높아 진다는 것을 의미한다. 2 단계에서는 수면 시간이 부모 감독에 $p<.10$ 수준에서 유의한 부적(-)인 영향을 미쳤으나 과잉간섭 과 합리적 설명에 유의한 영향을 미치지 않았다. 이는 미미한 수준에서 수면 시간이 증가할수록 부모감독이 감소하는 것을 의미한다. 3 단계에서는 수면 시간과 과잉 간섭이 학교적응에 유의한 부적(-)인 영향을 미쳤고, 부모 감독과 합리적 설명이 학교적응에 유의한 정적(+) 영향을 미치는 것으로 나타났다. 이는 수면 시간과 부모의 과잉간섭이 감소할수록 학교적응 수 준이 높아지고, 부모의 감독과 합리적 설명 수준이 높아질수 록 학교적응 수준이 높아지는 것을 의미한다. 3 단계의 수면 시 간을 1 단계의 매개변수가 없을 때의 수면 시간과 비교했을 때 표준화회귀계수 $(\beta)$ 값이 작아지고 학교적응에 유의한 결과에 서 부모의 양육태도는 수면 시간과 학교적응간의 관계에서 부 분매개 역할을 하는 것으로 볼 수 있다. 이러한 매개효과에 대 해 살펴보기 위해 Sobel test를 실시한 결과, 부모양육태도 중 에서 부모감독만이 수면 시간과 학교적응 간의 관계에서 $z=$ $-3.385(p<.001)$ 로 유의하게 나타나 매개효과가 있는 것으로 나타났다.

\section{논의 및 결론}

본 연구는 한국아동청소년패널조사 초1패널 초등학교 4학년 자료와 중 1 패널 중학교 1학년, 고등학교 1학년 자료를 사용하 여 초중고생의 수면 시간이 학교적응에 미치는 영향과 부모양 육태도의 매개효과를 살펴보았다. 본 연구의 결과를 요약하고 논의하면 다음과 같다.

첫째, 수면 시간과 학교적응과의 관계에서 초등학교 4학년 은 수면 시간이 증가할수록 학교적응 수준이 높아지는 것으로 나타났다. 그러나 중학교 1학년과 고등학교 1학년은 수면 시 간이 증가할수록 학교적응 수준이 감소하였다. 초등학교 4학 년의 수면 시간이 길수록 학교적응에 긍정적인 영향을 미쳤 다는 연구결과는 짧은 수면 시간이 학업성취 등의 학교적응에 부정적인 영향을 미친다고 보고한 선행연구 결과(Dewald et al., 2010; Lazaratou et al., 2005; Wolfson \& Carskadon, 1998)와 일치하였다. 또한 아동의 수면 시간이 길수록 IQ, 학업성취,
유능함 등의 학교적응에 긍정적인 영향을 미쳤다고 보고한 연 구결과나 유아의 수면 시간이 제한될수록 유치원의 적응 수준 이 낮았다는 연구결과(Bates et al., 2002; Gruber et al., 2010)와 도 유사하였다. 이러한 결과는 초등학교를 기준으로 하여 연 령이 낮아질수록 충분한 수면 시간이 학교적응에 있어서 중요 한 요인이라는 것을 의미한다고 볼 수 있다.

한편, 중학교 1 학년과 고등학교 1학년의 수면 시간이 길수 록 학교적응 수준에 부정적인 영향을 미쳤다는 본 연구의 결 과는 청소년의 수면 시간이 짧아질수록 주간 졸림 증상이 증 가하였고, 주간 졸림 증상이 증가할수록 수업만족, 학업성취 등이 감소하였다는 선행연구결과(Drake et al., 2003)와 차이 가 있었다. 또한 높은 학업성취를 보이는 중고등학생이 수면 시간이 길었다는 연구결과나 8시간 이하의 수면 시간을 취하 는 청소년은 수면 시간이 긴 청소년에 비해 더 피곤하거나 삶 에 대해 덜 긍정적이며 낮은 학업성취를 보였다는 연구결과 (Chung \& Cheung, 2008; Perkinson-Gloor et al., 2013)와도 차 이가 있었다. 이러한 차이는 본 연구가 학습활동, 학교규칙, 교 우관계, 교사관계 등의 학교적응에 초점을 둔 것과는 달리 외 국의 연구들은 주로 학업성취에 초점이 맞추어진 데서 비롯된 차이라고 추측해 볼 수 있다. 또한 Statistics Korea (2014)의 조 사에서 학습시간이 고등학생 8 시간 28 분, 중학생 7 시간 16 분, 초등학생 5 시간 23 분이라는 결과에 비추어 볼 때 우리나라의 경우, 다른 나라에 비해 부모의 교육열이 높고 입시에 대한 과 열 경쟁으로 인해 중고등학교에 올라가면서 공부를 열심히 하 는 학생들의 경우, 잠을 줄여서라도 노력하는 모습을 보이는 반면에 학교생활에 흥미가 없거나 포기한 학생일수록 잠을 더 자는 것으로 추측해 볼 수 있다. 우리나라와 같이 경쟁적 교육 환경에서 적정 수면 시간 이상의 수면은 학업포기와 더불어 학교생활에 대한 실패를 의미하는 것일 수 있다. 본 연구의 결 과는 중고등학생의 경우, 기존에 밝히지 못했던 긴 수면이 학 교적응에 있어서 해롭다는 것을 보여준 결과라고 생각된다.

둘째, 수면 시간과 부모의 양육태도와의 관계에서 초등학 교 4학년은 수면 시간이 증가할수록 부모의 합리적 설명이 증 가하는 것으로 나타났다. 그러나 중학교 1학년과 고등학교 1 학년은 수면 시간이 증가할수록 부모감독 수준이 감소하였다. 이는 지금까지 대부분의 선행연구(Bates et al., 2002; Brand et al., 2009a; de Jong, 2012; Labree et al., 2015; Meijer et al., 2001; Owens-Stively et al., 1997; Seifer et al., 1996)에서 부모의 양육태 도가 자녀의 수면 시간이나 질에 영향을 미쳤다는 결과와는 달리 처음으로 자녀의 수면 시간이 부모의 양육태도에 영향을 미친다는 것을 입증한 결과로서 어린 영유아뿐만 아니라 아동 
과 청소년의 수면 문제가 부모의 수면, 정신 건강, 양육 스트 레스 등 부모 특성에 영향을 미쳤다고 한 선행연구 결과와도 맥락적으로 유사하였다(Martin et al., 2007; Meltzer \& Mindell, 2007; Smedje et al., 1998). 특히 본 연구의 결과는 발달 시기별 로 그 결과가 달랐는데 초등학교 시기에는 아동의 수면 시간 이 증가할수록 왜 그래야 하는지에 대해 설명해 주는 부모의 합리적인 설명이 증가하지만, 잠을 줄여서라도 공부에 매진해 야 할 중고등학교 시기에 수면 시간이 증가할수록 부모의 감 독 수준이 줄어드는 것은 자녀는 학업을 포기하고 부모는 자 녀가 말을 해도 듣지 않으므로 자녀에 대해 포기해 버린 것이 라고 추측해 볼 수 있다(S. H. Jeong, 2009; Kerr \& Stattin, 2003; Reitz et al., 2006). 이는 본 연구에서 사용된 측정도구가 합리 적 설명 3 문항, 부모감독 3 문항으로 매우 축약된 도구를 사용 했기에 일반화하기에는 제한점이 있지만 자녀의 수면 시간이 부모의 양육태도에 영향을 미친다는 아동효과를 보여준 중요 한 증거라고 판단된다.

셋째, 수면 시간과 학교적응 간의 관계에서 부모양육태도 가 매개효과가 있는 것으로 나타났다. 즉, 초등학교 4학년은 수면 시간이 학교적응에 유의하지 않게 되면서 부모양육태도 가 완전 매개역할을 하였고, 부모양육태도 중에서 합리적 설 명이 매개효과가 있음이 확인되었다. 또한 중학교 1학년과 고 등학교 1학년은 수면 시간이 학교적응에 그대로 유의한 결과 에서 부모양육태도가 부분 매개역할을 하였고, 부모감독이 매 개 효과가 있는 것으로 나타났다. 본 연구의 결과는 영아의 수 면문제가 모아애착을 감소시키고 모아애착을 매개로 영아문 제행동을 더욱 증가시켰다고 보고한 Bae (2014)의 연구결과 와 부분적으로 유사하였다. 그리고 아동과 청소년의 수면 시 간이 학교적응에 직접적인 영향을 미치지 않았지만 우울과 자 기보호능력을 완전 매개로 하여 학교적응에 간접적으로 부정 적인 영향을 미치는 것으로 나타난 결과(Choi, 2012)와도 맥락 적으로 유사하였다. 하지만 본 연구 결과와 차이가 있는 점으 로 매개변수 유형도 다르지만 Choi (2012)의 연구는 수면 시간 이 짧을수록 우울을 증가시켜 학교적응에 부정적인 영향을 미 치고, 수면 시간이 길어질수록 자기보호능력을 증가시켜 학교 적응에 긍정적인 영향을 미쳤다는 것으로서 결국은 짧은 수면 의 문제만을 강조한 것이다. 이는 표본의 전국적 대표성과 충 분한 표본수를 사용하여 분석한 본 연구와 달리 Choi (2012) 의 연구에서는 비확률표집을 통해 수집한 초등학생 171 명과 중학생 335 명의 자료를 함께 통합하여 분석한데서 비롯된 차 이라고 생각된다. 따라서 향후 대표성이 높은 표본을 사용하 고 초등학생과 중학생을 분리하여 진행한 반복연구를 통해서
학교적응에 있어서 저학년으로 갈수록 짧은 수면이 문제가 될 수 있지만 고학년으로 올라갈수록 긴 수면이 더 문제가 되는 지에 대해 재확인해 볼 필요가 있다.

본 연구의 결과는 다음과 같은 함의를 제공해 준다. 첫째, 초등학생은 수면 시간이 길수록 학교적응에 긍정적인 영향을 미쳤지만 중고등학생은 수면 시간이 길수록 학교적응에 부정 적인 영향을 미치는 것으로 나타났다. 이러한 결과는 수면 시 간이 발달단계마다 학교적응에 다르게 영향을 미친다는 것을 의미하므로 발달단계별로 수면 시간에 대한 차별화된 접근방 식이 필요할 것으로 보인다. 즉, 초등학교 시기에는 수면을 많 이 하도록 도와주는 것이 필요하지만 나이가 들어서는 학교적 응에 학업성취가 포함되므로 중고등학교 시기에는 적정하게 수면을 할 수 있도록 도와주어야 한다. 이러한 맥락에서 최근 일부 교육청은 장시간의 학습시간, 치열한 입시경쟁, 학업스 트레스 등을 덜어주고 충분한 수면을 취하도록 초중고생의 등 교시간을 9 시로 늦추는 정책을 펼치고 있다. 하지만 아직까지 이에 대한 긍정적인 측면과 부정적인 측면으로 인해 찬반론이 오가고 있는 시점에서 초등학생은 등교시간을 9시로 늦추는 것도 좋지만 초등학생과 다르게 중고등학생은 이전과 동일하 게 시행하는 것도 생각해 볼 필요가 있다.

또한 민감도(sensitivity) 분석 차원에서 고등학교를 인문계 와 전문계로 구분하여 살펴본 결과에서 인문계는 본 연구의 결과와 동일하였으나 전문계는 수면 시간이 학교적응에 영향 을 미치지 않았다. 전문계는 인문계에 비해 대학입시의 부담 에서 상대적으로 자유롭기 때문에 수면 시간이 미치는 영향이 적었을 것이라 판단된다. 이는 수면 시간에서 교육환경의 중 요성을 보여주는 것이라 생각되므로 수면 시간이 학교적응에 미치는 영향을 좀 더 다각적으로 살펴보기 위해서는 생활시 간 조사를 통해 학년이 올라갈수록 왜 수면 시간이 줄어들 수 밖에 없는지를 분석 할 필요가 있다. 우리나라의 교육환경에 서는 아마도 사교육이 미치는 영향이 크므로 사교육이 미치는 학교적응에 대한 효과가 수면 시간이 미치는 영향으로 나타났 을 가능성이 존재한다(N. R. Park \& Chung, 2012). 따라서 이 에 대한 면밀한 향후 분석도 요구된다.

둘째, 수면 시간은 부모의 양육태도에 영향을 미칠 정도로 중요한 요인으로 나타났다. 따라서 자녀의 수면 시간에 대한 중요성을 부모교육을 통해 가르칠 필요가 있다. 구체적인 내 용으로는 초등학생의 학부모에게는 충분한 수면이 학교적응 에 긍정적인 영향을 미친다는 것과 미국 수면재단의 적정 수 면 시간(9-11시간) 및 본 연구의 결과에서 보여준 것처럼 평 소에 9 시간 이상의 수면이 필요하다는 것을 안내해 줄 필요가 
있다. 특히 Rhie 등(2011)의 연구에서 초등학교 5-6학년의 수 면 시간을 제한하는 요인으로 개인적인 과외나 학원에 가는 것 등으로 확인된 결과에서 사교육을 많이 해서 잠을 빼앗기 는 것이 학교적응에 있어서 결코 유익하지 못하다는 것이 언 급될 필요가 있다. 중고등학생의 학부모에게는 학년이 올라갈 수록 긴 수면보다는 적정 수면을 취할 수 있도록 알려주되 미 국의 수면재단에서 제안한 기준(8-10시간)이 우리나라 중고 등학생들에게는 긴 수면에 해당하므로 그보다 한 단계 아래 정도가 좀 더 적절할 것이라는 것을 안내해 줄 필요가 있을 것 이다. 특히 잠을 많이 자는 중고등학생 자녀를 둔 부모에게는 자녀를 포기하지 않고 관리해 주는 것이 필요하다는 것을 강 조해 주어야 한다.

마지막으로 후속연구를 위한 제언을 하면 다음과 같다. 먼 저 본 연구에서는 초중고생의 수면 시간이 자기보고식 설문 을 통해 이루어졌다. 이는 기억에 따라 회상 편견이 있을 수 있 다. 따라서 후속 연구에서는 수면 시간을 보다 객관적으로 측 정할 수 있도록 액티그래프의 사용 등을 통해 초중고생의 수 면 시간을 정확하게 측정할 필요가 있다. 또한 본 연구에서는 수면의 양적인 측면인 수면 시간과 학교적응과의 관계를 살펴 보았는데 후속연구에서는 숙면 여부 등 수면의 질적인 측면을 묻는 문항을 보완하여 학교적응과의 관계를 살펴볼 필요가 있 다. 그리고 2차 자료 분석의 한계로 인해 부모양육태도의 문 항이 매우 축약된 문항으로 이루어졌으므로 향후 문항에 대한 보완이 필요할 것으로 생각된다. 마지막으로 본 연구에서는 수면 시간과 학교적응과의 관계에 대한 양적인 연구를 진행하 였는데 후속연구에서는 중고등학생을 대상으로 수면 시간과 학교적응에 대한 질적 연구를 통해 심층적인 분석이 이루어질 필요가 있다.

\section{Notes}

A part of this article was presented as a poster at the 2015 annual fall conference of the Korean Association of Child Studies and another part of this article was presented orally at the 2015 5th conference of the Korea Children and Youth Panel. The earlier versions were modified thoroughly for this article.

\section{Conflict of Interest}

No potential conflict of interest relevant to this article was reported.

\section{References}

\section{In English}

BaHammam, A., Al-Faris, E., Shaikh, S., \& Saeed, A. B. (2006). Sleep problems/habits and school performance in elementary school children. Sleep and Hypnosis, 8(1), 12-18. Retrieved from https://www.researchgate.net/profile/Ahmed_BaHammam/ publication/286159333_School_performance_and_sleep/ links/56667f8308ae4931cd6273af.pdf

Baron, R. M., \& Kenny, D. A. (1986). The moderator-mediator variable distinction in social psychological research: Conceptual, strategic, and statistical considerations. Journal of Personality and Social Psychology, 51(6), 11731182. doi.org:10.1037/0022-3514.51.6.1173

Bates, J. E., Viken, R. J., Alexander, D. B., Beyers, J., \& Stockton, L. (2002). Sleep and adjustment in preschool children: Sleep diary reports by mothers relate to behavior reports by teachers. Child Development, 73(1), 62-74. doi:10.1111/1467-8624.00392

Beebe, D. W. (2011). Cognitive, behavioral, and functional consequences of inadequate sleep in children and adolescents. The Pediatric Clinics of North America, 58(3), 649-666. doi:10.1016/j.pcl.2011.03.002

Brand, S., Gerber, M., Hatzinger, M., Beck, J., \& HolsboerTrachsler, E. (2009b). Evidence for similarities between adolescents and parents in sleep patterns. Sleep Medicine, 10(10), 1124-1131. doi:10.1016/j.sleep.2008.12.013

Brand, S., Hatzinger, M., Beck, J., \& Holsboer-Trachsler, E. (2009a). Perceived parenting styles, personality traits and sleep patterns in adolescents. Journal of Adolescence, 32(5), 1189-1207. doi:10.1016/j.adolescence.2009.01.010

Bruni, O., Ferini-Strambi, L., Russo, P. M., Antignani, M., Innocenzi, M., Ottaviano, P., . . Salvatore, O. (2006). Sleep disturbances and teacher ratings of school achievement and temperament in children. Sleep Medicine, 7(1), 43-48. doi:10.1016/j.sleep.2005.09.003

Chung, K.-F., \& Cheung, M.-M. (2008). Sleep-wake patterns and sleep disturbance among Hong Kong Chinese adolescents. Sleep, 31(2), 185-196. Retrieved from http:// www.ncbi.nlm.nih.gov/pmc/articles/PMC2225574/pdf/ aasm.31.2.185.pdf

Coulombe, J. A., Reid, G. J., Boyle, M. H., \& Racine, Y. (2011). Sleep problems, tiredness, and psychological symptoms among healthy adolescents. Journal of Pediatric Psychology, 36(1), 25-35. doi:10.1093/jpepsy/jsq028

de Jong, E., Stocks, T., Visscher, T. L., HiraSing, R. A., Seidell, J. C., \& Renzaho, A. (2012). Association between sleep duration and overweight. International Journal of Obesity, 36, 1278- 
1284. doi:10.1038/ijo.2012.119

Dewald, J. F., Meijer, A. M., Oort, F. J., Kerkhof, G. A., \& Bögels, S. M. (2010). The influence of sleep quality, sleep duration and sleepiness on school performance in children and adolescents: A meta-analytic review. Sleep Medicine Reviews, 14(3), 179-189. doi:10.1016/j.smrv.2009.10.004

Drake, C., Nickel, C., Burduvali, E., Roth, T., Jefferson, C., \& Pietro, B. (2003). The Pediatric Daytime Sleepiness Scale (PDSS): Sleep habits and school outcomes in middle school children. Sleep, 26(4), 455-460. Retrieved from

https://www.nationaljewish.org/NJH/media/pdf/ Meltzer\%20References/Drake-(2003)-The-PDSS-SleepHabits-School-Outcomes.pdf

Fredriksen, K., Rhodes, J., Reddy, R., \& Way, N. (2004). Sleepless in Chicago: Tracking the effects of adolescent sleep loss during the middle school years. Child Development, 75(1), 84-95. doi:10.1111/j.1467-8624.2004.00655.x

Gruber, R., Laviolette, R., Deluca, P., Monson, E., Cornish, K., \& Carrier, J. (2010). Short sleep duration is associated with poor performance on IQ measures in healthy school-age children. Sleep Medicine, 11(3), 289-294. doi:10.1016/ j.sleep.2009.09.007

Hirshkowitz, M., Whiton, K., Albert, S. M., Alessi, C., Bruni, O., DonCarlos, L., . . . Neubauer, D. N. (2015). National Sleep Foundation's sleep time duration recommendations: Methodology and results summary. Sleep Health, 1(1), 40-45. doi:10.1016/j.sleh.2014.12.010

Kalak, N., Gerber, M., Kirov, R., Mikoteit, T., Pühse, U., HolsboerTrachsler, E., \& Brand, S. (2012). The relation of objective sleep patterns, depressive symptoms, and sleep disturbances in adolescent children and their parents: A sleep-EEG study with 47 families. Journal of Psychiatric Research, 46(10), 1374-1382. doi:10.1016/j.jpsychires.2012.07.006

Kerr, M., \& Stattin, H. (2003). Parenting of adolescents: Action or reaction? In A. Crouther \& A. Booth (Eds.), Children's influence on family dynamics: The neglected side of family relationships (pp. 121-151). Mahwah, NJ: Lawrence Erlbaum Associates. Retrieved from

https://www.researchgate.net/profile/Pamela_Cole/ publication/232577509_The_developmental_ course_from_child_effects_to_child_effectiveness/ links/55a4e62a08ae81aec9131 ef6.pdf\#page $=132$

Labree, L. J. W., van de Mheen, H., Rutten, F. F. H., Rodenburg, G., Koopans, G. T., \& Foets, M. (2015). Sleep duration differences between children of migrant and native origins. Journal Public Health, 23(3), 149-156. doi:10.1007/ s10389-015-0665-8

Lazaratou, H., Dikeos D. G., Anagnostopoulos, D. C., Sbokou O., \& Soldatos, C. R. (2005). Sleep problems in adolescence: A study of senior high school students in Greece.
European Child and Adolescent Psychiatry, 14(4), 237-243. doi: 10.1007/s00787-005-0460-0

Martin, J., Hiscock, H., Hardy, P., Davey, B., \& Wake, M. (2007). Adverse associations of infant and child sleep problems and parent health: An Australian population study. Pediatrics, 119(5), 947-955. doi:10.1542/peds.2006-2569

Meijer, A. M., Habekothé, R. T., \& van den Wittenboer, G. L. (2001). Mental health, parental rules, and sleep in preadolescents. Journal of Sleep Research, 10(4), 297-302. doi:10.1046/j.1365-2869.2001.00265.x

Meltzer, L. J., \& Mindell, J. A. (2007). Relationship between child sleep disturbances and maternal sleep, mood, and parenting stress: A pilot study. Journal of Family Psychology, 21(1), 6773. doi:10.1037/0893-3200.21.1.67

Owens-Stively, J., Frank, A., Hagino, O., Spirito, A., Arrigan, M., \& Alario, A. J. (1997). Child temperament, parenting discipline style, and daytime behavior in childhood sleep disorders. Developmental and Behavioral Pediatrics, 18(5), 314-321.

Perkinson-Gloor, N., Lemola, S., \& Grob. A. (2013). Sleep duration, positive attitude toward life, and academic achievement: The role of daytime tiredness, behavioral persistence, and school start times. Journal of Adolescence, 36(2), 311-318. doi:10.1016/j.adolescence.2012.11.008

Philips, N., Sioen, I., Michels, N., Sleddens, E., \& de Henauw, S. (2014). The influence of parenting style on health related behavior of children: Findings from the ChiBS study. International Journal of Behavioral Nutrition and Physical Activity, 11(1), 1-23. doi:10.1186/s12966-014-0095-y

Reitz, E., Dekovic, M., Meijer, A. M., \& Engels, R. C. M. E. (2006). Longitudinal relations among parenting, best friends, and early adolescent problem behavior testing bidirectional effects. Journal of Early Adolescent, 26(3), 272-295. doi:10.1177/0272431606288591

Sadeh, A., Tikotzky, L., \& Scher, A. (2010). Parenting and infant. Sleep Medicine Reviews, 14(2), 89-96. doi:10.1016/ j.smrv.2009.05.003

Seifer, R., Sameroff, A. J., Dickstein, S., Hayden, L. C., \& Schiller, M. (1996). Parental psychopathology and sleep variation in children. Child and Adolescent Psychiatric Clinics of North America, 5(3), 715-727.

Shochat, T., Cohen-Zion, M., \& Tzischinsky, O. (2014). Functional consequences of inadequate sleep in adolescents: A systematic review. Sleep Medicine Reviews, 18(1), 75-87. doi:10.1016/j.smrv.2013.03.005

Smedje, H., Broman, J.-E., \& Hetta, J. (1998). Sleep disturbances in Swedish pre-school children and their parents. Nordic Journal of Psychiatry, 52(1), 59-67. doi:10.1080/080394898422580

Spilsbury, J. C., Storfer-lasser, A., Drotar, D., Rosen, C. L., Kirchner, L. H., \& Redline, S. (2005). Effects of the home 
environment on school-aged children's sleep. Pediatrics, 28(11), 1419-1427. Retrieved from http://www. journalsleep.org/Articles/281113.pdf

Wolfson, A. R., \& Carskadon, M. A. (1998). Sleep schedules and daytime functioning in adolescents. Child Development, 69(4), 875-887. doi: 10.1111/j.1467-8624.1998.tb06149.x

Yang, C.-K., Kim, J. K., Patel, S. R., \& Lee, J.-H. (2005). Agerelated changes in sleep/wake patterns among Korean teenagers. Pediatrics, 115(1), 250-256. doi:10.1542/ peds.2004-0815G

\section{In Korean}

Bae, J.-I. (2014). Infant problem behaviors and adaptation in child care centers: The influences of a mother and infant sleep problems. The Journal of Korea Open Association for Early Childhood Education, 19(4), 125-143.

Choi, K. I. (2012). An effect of sleeping time on school adaptation of youths: Mediated by depression and ability of selfprotection. Forum for Youth Culture, 30, 126-166.

Ha, Y. M., \& Park, H. J. (2014). Relationships between short sleep, obesity, and screen time in high school students. Journal of Korean Biological Nursing Science, 16(2), 80-89. doi:10.7586/jkbns.2014.16.2.80

Huh, M. Y. (2000). The study for the development and validation of 'parenting behavior inventory' perceived by adolescent (Unpublished doctoral dissertation). Ewha Womans University, Seoul, Korea.

Jeong, J.-H., Jang, Y.-E., Lee, H.-W., Shim, H.-B., \& Choi, J.S. (2013). Sleep and suicidal risk factors in Korean high school students. Sleep Medicine and Psychophysiology, 20(1), 22-30. doi:10.14401/KASMED.2013.20.1.022

Jeong, S. H. (2009). A study on longitudinal interaction between parenting behavior and adolescents' delinquency. Korean Journal of Social Welfare Studies, 40(4), 349-376.

Kim, S. J., \& Chung, I.-J. (2015a). Bidirectional associations between the negative emotionality of 0 -to 3-year-old children and maternal warmth/reactivity. Korean Journal of Child Studies, 36(4), 1-16. doi.org/10.5723/KJCS.2015.36.4.1

Kim, S. J., \& Chung, I.-J. (2015b, Oct). The effect of sleep duration on youth's school adjustment mediated by parenting behavior. Paper presented at $5^{\text {th }}$ Conference of Korea Children and Youth Panel, Seoul, Korea.

Lee, B.-H., \& Kang, D. K. (2014). A study of school maladjustment action factors in secondary school students. Journal of Education and Culture, 20(3). 125-148.

Lee, J. G., Kang, J. G., Rhie, S. K., \& Chae, K. Y. (2013). Impact of sleep duration on emotional status in adolescents.
Journal of Korea Child Neurology Society, 21(3), 100-110.

Lee, S. G. (2012). Longitudinal analysis on the relationship between parenting behaviors and delinquent behaviors in adolescence. Korean Journal of Family Social Work, 36(6), $157-185$

Min, B. S. (1991). The influence of school life adjustment and selfconcept on academic achievement (Unpublished master's thesis). Hongik University, Seoul, Korea.

Park, H. J. (2015). Effect of sleep duration on suicidal ideation in Korean adolescents. The Journal of the Korean Society of School Health, 28(1), 1-9.

Park, N. R., \& Chung, I. J. (2012). The influence of parental neglect and overprotection on youth's psychosocial adjustment: Focusing on moderating effect of private tutoring. Journal of the Korean Society of Child Welfare, 37, 139-164.

Park, Y. H. (2014). Role of self-regulation in the relations among media use, emotional-behavioral problems, and school adjustment for middle school students. Korean Journal of Educational Psychology, 28(4), 691-710. doi:10.17286/ KJEP.2014.28.4.07

Rhie, S. K., Lee, S. H., \& Chae, K. Y. (2011). Sleep patterns and school performance of Korean adolescents assessed using a Korean version of the pediatric daytime sleepiness scale. Korean Journal of Pediatrics, 54(1), 29-35. doi:10.3345/ kjp.2011.54.1.29

Seo, W. S., Koo, B. H., Kim, M. J., Rho, Y. H., Sung, H. M., \& Shin, J. H. (2008). Preliminary study of children's sleep problems in an elementary school in Daegu. Korean Journal of Child and Adolescent Psychiatry, 19(3), 156-161

Song, H. S., Park, Y. M., Nam, M., \& Kim, L. (2000). Sleep patterns of middle and high school students in Seoul. Sleep Medicine and Psychophysiology, 7(1), 51-59.

Statistics Korea. (2014). Life style survey. Retrieved from http:// kostat.go.kr/survey/lifestyle/

Yoo, K.-H. (2004). A survey study on the sleep in adolescence. Journal of Soonchunhyang Medical Science, 10(3), 20252530 .

\section{ORCID}

Soo Jung Kim http://orcid.org/0000-0003-3521-8360

Ick-Joong Chung http://orcid.org/0000-0002-3426-7956

Received January 21, 2016

Revision received May 26, 2016

Accepted May 28, 2016 